\title{
DAMPAK DEVALUASI YUAN TERHADAP PEREKONOMIAN INDONESIA PENDEKATAN MODEL PERSAMAAN SIMULTAN
}

\author{
Impact of Yuan Devaluation on Indonesian Economy \\ Simultaneous Equation Model Approach
}

\author{
Febria Ramana ${ }^{1}$, Nasrudin ${ }^{2}$ \\ ${ }^{1}$ Badan Pusat Statistik Kabupaten Kaur, Jl. Peltu M. Ilyas T. Panji Alam, Kompleks Perkantoran \\ Pemkab Kaur, Padang Kempas, Kaur 38963, Indonesia \\ 2Sekolah Tinggi IImu Statistik, Jl. Otto Iskandardinata, Jakarta 13330, Indonesia \\ email: febriarmn@gmail.com
}

Naskah diterima:09/07/2017; Naskah direvisi: 27/01/2018; Disetujui diterbitkan: 14/03/2018 Dipublikasikan online: 31/07/2018

\begin{abstract}
Abstrak
Penelitian ini bertujuan untuk menganalisis dampak devaluasi yuan terhadap perekonomian Indonesia. Penelitian ini menggunakan skenario simulasi model persamaan simultan dengan metode estimasi Two Stage Least Square (2SLS). Hasil dari analisis ini menunjukkan bahwa devaluasi yuan berdampak signifikan terhadap perekonomian Indonesia melalui jalur perdagangan dan investasi. Pada blok perdagangan, devaluasi yuan menyebabkan ekspor Indonesia ke negara lain mengalami penurunan, terutama ekspor ke Republik Rakyat Tiongkok (RRT) karena devaluasi yuan lebih besar dibandingkan rupiah. Hal ini membuat produk RRT relatif lebih murah dibandingkan Indonesia. Pada blok investasi, total investasi meningkat karena investor beralih dari RRT ke Indonesia yang didorong tingkat pengembalian modal di RRT menurun. Sementara itu, pada blok moneter, nilai rupiah dan PDB Indonesia menurun akibat penurunan net ekspor lebih besar dibandingkan peningkatan FDI. Devaluasi rupiah pun memicu imported inflation. Secara keseluruhan, devaluasi yuan berdampak negatif bagi perekonomian Indonesia. Oleh karena itu, penting bagi Indonesia untuk mengurangi ketergantungan terhadap RRT, terutama dalam perdagangan. Hal ini dapat dilakukan dengan diversifikasi pasar dan peningkatan kualitas produk ekspor.
\end{abstract}

Kata Kunci: Devaluasi yuan, Perekonomian Indonesia, 2SLS, Simulasi

\begin{abstract}
This paper examines and provides an analysis regarding the impact of an economic shock, yuan devaluation, on the Indonesian economy. We analyze a simulation scenario by using simultaneous equation model with two-stage least square (2SLS) method. Empirical findings exhibit that shock has the significant impact on Indonesian economy through both of trade and investment transmissions. In trade block, Indonesian export to China has the most decreasing rather than others countries because of yuan more decrease than rupiah. In investment block, a total of investment gets the impact to rise, particularly in Foreign Direct Investment (FDI) from China, caused by decreasing wealth of foreign investors in China. Meanwhile, in the monetary block, the value of rupiah and Indonesian GDP simultaneously get the impact to decline, whereas yuan devalution leads Indonesian inflation to rise. Therefore, it is essential for the government to decrease Indonesian dependence on China, particularly in trade block. Some options which government should implement are market diversification and increasing export products quality.
\end{abstract}

Keywords: Yuan Devaluation, Indonesian Economy, 2SLS, Simulation

JEL Classifications: F10, F17, F41 
PENDAHULUAN

Indonesia beberapa kali mendapatkan dampak dari gejolak eksternal. Gejolak yang baru baru ini berdampak pada penurunan performa ekonomi Indonesia adalah gejolak ekonomi yang berasal dari Republik Rakyat Tiongkok (RRT). Menurut Gubernur Bank Indonesia, Agus Martowardojo, gejolak ekonomi di RRT telah menyebabkan kemunduran ekonomi Indonesia pada tahun 2015 (Sari, 2015). Hal ini terlihat pada kuartal III tahun 2015, nilai tukar rupiah terhadap dolar Amerika terdepresiasi hingga Rp14.657. Jika dibandingkan dengan nilai tukar rupiah pada awal 2015, nilai rupiah melemah hingga $16,52 \% \quad$ (IMF, 2016). Selain melemahnya nilai tukar rupiah, pertumbuhan ekonomi Indonesia juga mendapat dampak negatif akibat gejolak tersebut. Pertumbuhan PDB Indonesia hanya sebesar 4,79\%. Angka ini mengalami penurunan sebesar $0,23 \%$ poin dari tahun sebelumnya (BPS, 2016) dan berada di bawah target pertumbuhan ekonomi Indonesia di tahun itu.

Pada 11 Agustus 2015, perlambatan pertumbuhan ekonomi RRT memaksa pemerintah RRT untuk mendevaluasi yuan terhadap dolar Amerika hampir 2\%. Berdasarkan data Bloomberg, nilai yuan didevaluasi dari 6,200 yuan per dolar Amerika menjadi 6,325 yuan per dolar Amerika. Devaluasi ini bertujuan untuk mendorong kinerja ekspor RRT sehingga diharapkan dapat meningkatkan ekonomi mereka (Mar'ah, Suhadak, \& Hidayat, 2016). Selain itu, menurut Bloomberg (2016), devaluasi ini juga bertujuan untuk menunjukkan kepada IMF bahwa yuan dapat digunakan sebagai salah satu mata uang cadangan dunia.

Kebijakan Bank Rakyat RRT (PBOC) untuk mendevaluasi yuan merangsang mata uang tersebut terus menurun dan juga memberi dampak pada ekonomi global, termasuk di Indonesia. Devaluasi ini memengaruhi perekonomian Indonesia diindikasikan karena adanya keterkaitan yang kuat antara RRT dan Indonesia melalui jalur perdagangan dan keuangan. Berdasarkan data Badan Pusat Statistik (BPS), RRT merupakan negara dengan nilai ekspor dan impor terbesar bagi Indonesia. Selain itu, berdasarkan data Badan Koordinasi Penanaman Modal (BKPM), RRT juga merupakan salah 
satu dari sepuluh negara yang memiliki nilai investasi terbesar di Indonesia.

Berdasarkan Bank Dunia, pertumbuhan ekonomi RRT akan terus menurun dalam tiga tahun ke depan hingga 2018. Perlambatan ekonomi pertumbuhan RRT ini akan memberi tekanan pada mata uang mereka. Union Bank of Switzerland (UBS) memperkirakan bahwa nilai tukar RRT tidak akan berada di bawah 6,8 yuan per dolar Amerika pada akhir 2016. Sementara itu, Bank of America Corp dan Goldman Sachs memperkirakan bahwa nilai tukar RRT akan berada di 7 Yuan per dolar Amerika pada tahun yang sama (Bloomberg dan CNBC, 2016). Devaluasi ini diindikasikan akan berdampak signifikan terhadap perekonomian Indonesia. Oleh karena itu, penelitian ini tertarik untuk mengkaji dan menganalisa dampak dari devaluasi yuan terhadap perekonomian Indonesia.

Penelitian sebelumnya masih sedikit yang menyediakan informasi mengenai dampak devaluasi yuan, berikut beberapa penelitian tersebut: Hooy, Law, \& Chan (2015), Chaitanya (2016), Soleymani, Chua, \& Fattah (2016), DBS Group Research (2015), Shik (2016), Harahap et al (2015). Selain penelitian empiris, penelitian ini juga merujuk pada penelitian mengenai teori contagion dari penelitian Forbes (2012).

Dari beberapa penelitian di atas, penelitian empiris hanya memeriksa dampak langsung dari devaluasi yuan terhadap ekspor dan indikator ekonomi lainnya. Padahal, dampak tidak langsung juga penting diketahui agar kebijakan yang diambil menjadi lebih tepat. Oleh karena itu, penelitian ini memeriksa tidak hanya dampak langsung, tetapi juga dampak tidak langsung terhadap perekonomian Indonesia Penelitian ini juga mampu menjawab jalur transmisi pengaruh devaluasi yuan sehingga dapat masuk ke perekonomian Indonesia.

\section{METODE}

Dampak devaluasi yuan dalam makalah ini akan diteliti melalui hubungan investasi dan perdagangan antara RRT-Indonesia. Besarnya dampak gejolak yuan akan ditunjukkan dari hasil simulasi model. Kinerja perekonomian Indonesia akan ditunjukkan oleh indikator ekonomi, yakni PDB, inflasi, suku bunga, dan nilai tukar rupiah terhadap dolar AS. Data tersebut menggunakan periode tahunan selama 1995-2014 yang bersumber dari United Nation Conference on Trade and 
Development (UNCTAD), BKPM, International Financial Statistics (IFS), dan Bank Dunia. Semua data yang menggunakan satuan rupiah telah diriilkan dengan deflator PDB, seperti nilai PDB, ekspor, impor, dan investasi. Dengan kata lain, variabel tersebut merupakan nilai atas dasar harga konstan pada tahun 2005.

Penelitian ini menggunakan persamaan simultan karena adanya hubungan kausalitas dua arah antara variabel ekonomi. Model ini terdiri dari 14 persamaan struktural dan 12 persamaan identitas, yang disusun menjadi tiga blok, yaitu: sektor investasi, perdagangan, dan moneter. Jumlah variabel endogen yang nilainya ditentukan dalam sistem terdapat 26 variabel, sedangkan jumlah variabel eksogen berjumlah 17 variabel. Berikut model persamaan yang dibangun dalam penelitian ini:

$$
\begin{array}{ll}
Y_{t} & =C R T_{t}+I_{t}+G_{t}+X_{t}-M_{t} \\
F D I_{t} & =C_{t}+I A_{t}+I R_{t} \ldots \ldots \ldots \ldots \\
I_{t} & =D I_{t}+F D I_{t} \ldots \ldots \ldots \ldots \ldots \\
X_{t} & =X C_{t}+X A_{t}+X R_{t} \ldots \ldots \\
M_{t} & =M C_{t}+M A_{t}+M R_{t} \ldots \ldots \ldots \\
E A_{t} & =E I_{t} \times \frac{I H K a_{t}}{I H K i_{t}} \ldots \ldots \ldots \ldots \ldots \ldots
\end{array}
$$

$E C l_{t}=\frac{E C_{t}}{E l_{t}} \times \frac{\pi i_{t}}{\pi c_{t}}$

$R R I_{t}=R R_{t}-R I_{t}$

$R C l_{t}=\frac{\text { DRATEC }_{t}}{\text { DRATE }_{t}}$

INFAI ${ }_{t}=\frac{\pi a_{t}}{\pi i_{t}}$

$I N F C I_{t}=\frac{\pi c_{t}}{\pi i_{t}}$

$N X C_{t}=\frac{X c_{t}}{M c_{t}}$

$D I_{t}=f\left(R A I_{t}, Y_{t}, E I_{t}\right)$

$I C_{t}=f\left(R C l_{t}, Y_{t}, E C I_{t}\right.$, TOI $_{t}$, INFCl $\left._{t}\right) \cdot(14)$

$I A_{t}=f\left(R A I_{t}, Y_{t}, I N F A I_{t}\right)$

$I R_{t}=f\left(R R I_{t}, Y_{t}, E I_{t}, \mathrm{TOI}_{t}, \pi i_{t}\right)$

$X C_{t}=f\left(Y C_{t}, E C l_{t}, I N F C l_{t}\right)$.

$X A_{t}=f\left(E A_{t}, Y A_{t}, T O I_{t}, I N F A I_{t}\right)$.

$X R_{t}=f\left(E A_{t}, Y R_{t}\right)$

$M C_{t}=f\left(Y_{t}, E C I_{t}, \mathrm{INFCl}_{t}, \mathrm{TOI}_{t}\right)$

$M A_{t}=f\left(Y_{t}, E I_{t}, T O I_{t}, I N F A I_{t}\right)$

$M R_{t}=f\left(Y_{t}, T O R_{t}, E A_{t}, \pi i_{t}\right)$

$E I_{t}=f\left(N X C_{t}, \pi i_{t}, F D I_{t}\right)$

$\pi i_{t}=f\left(M 2_{t}, E A_{t}, Y_{t}\right)$

$R I_{t}=f\left(\pi i_{t}, R A_{t}, E A_{t}\right)$

$\operatorname{DRATE}_{t}=f\left(R I_{t}, M 2_{t}, Y_{t}\right)$ 
Keterangan:

$\mathrm{Y}_{\mathrm{t}}$ : PDB Indonesia

$\mathrm{CRT}_{\mathrm{t}}$ : Konsumsi Rumah Tangga

It : Investasi

Gt : Pengeluaran pemerintah

FDI $\quad$ : Investasi asing

TOr : Derajat Keterbukaan ROW

$\mathrm{X}_{\mathrm{t}} \quad$ : Total export

M : Total import

Dlt : Domestik investasi

$\mathrm{IC}_{\mathrm{t}}$ : FDI RRT ke Indonesia

$\mathrm{IA}_{\mathrm{t}} \quad$ : FDI US ke Indonesia

$\mathrm{IR}_{\mathrm{t}} \quad$ : FDI ROW ke Indonesia

$\mathrm{XC}_{\mathrm{t}} \quad$ : Ekspor Indonesia ke RRT

$X A_{t} \quad$ : Ekspor Indonesia ke US

$\mathrm{XR}_{\mathrm{t}}$ : Ekspor Indonesia ke ROW

$\mathrm{MA}_{\mathrm{t}}$ : Impor Indonesia dari US

$M_{t} \quad$ : Impor Indonesia dari RRT

$\mathrm{MR}_{\mathrm{t}} \quad$ : Impor Indonesia dari ROW

Elt : Kurs Nominal Rp/dolar

EAt : Kurs Riil Rp/dolar

$E_{t}$ : Kurs yuan/dolar

IHKit : IHK Indonesia

IHKat : IHK US

$\mathrm{RR}_{\mathrm{t}}$ : Lending Rate ROW

$\mathrm{RI}_{\mathrm{t}} \quad$ : Lending Rate Indonesia

RAt : Lending Rate US

пан : Inflasi US

$\pi i_{t} \quad$ : Inflasi Indonesia

TCt $\quad$ : Inflasi RRT

Drateit : Deposit Rate Indonesia

TOit :Derajat Keterbukaan Ind
$\mathrm{YC}_{\mathrm{t}} \quad$ : PDB RRT

$\mathrm{Pl}_{\mathrm{t}} \quad$ : IHP Indonesia

$\mathrm{PC}_{\mathrm{t}}$ : IHP RRT

YAt : PDB Amerika Serikat

$\mathrm{YR}_{\mathrm{t}}$ : PDB ROW

$\mathrm{M} 2 \mathrm{t} \quad$ : Jumlah Uang Beredar

Dratect: Deposit Rate RRT

RAlt : Fedrate $-\mathrm{BI}$ rate

Dalam penelitian ini, pembentukan model hanya menggunakan identifikasi order condition karena identifikasi rank condition sulit dilakukan dalam sistem persamaan besar. Dalam banyak aplikasi, peneliti mengasumsikan bahwa, kecuali ada kegagalan identifikasi yang jelas, sebuah persamaan yang memenuhi persyaratan order condition telah dianggap valid (Wooldridge, 2012). Oleh karena itu, dalam praktiknya order condition secara umum telah layak untuk memastikan suatu persamaan teridentifikasi atau tidak (Gujarati \& Porter, 2008).

Berdasarkan order condition, model ini masuk dalam kategori overidentified sehingga penelitian ini menggunakan metode estimasi two stage least square (2SLS) untuk memperkirakan parameter. Hasil estimasi ini akan disimulasikan untuk 
mengetahui dampak devaluasi yuan terhadap perekonomian Indonesia.

\section{Two Stage Least Square (2SLS)}

Metode 2SLS adalah metode yang paling banyak digunakan untuk estimasi model persamaan simultan. Ide dasar dari prosedur ini adalah mengatasi variabel endogen sebelah kanan yang berkorelasi dengan error menggunakan prediktor yang didapat dari reduced form atau disebut juga variabel instrumental. Hasil estimasi dari prosedur ini akan mendapatkan estimator yang konsisten (Gujarati \& Porter, 2008).

Saat order condition menghasilkan overidentified, 2SLS baik untuk digunakan. Hasil estimator 2SLS akan mendekati OLS jika $\mathrm{R}^{2}$ hasil regresi tahap pertama melebihi 0,8 . Hal ini karena hasil prediktor variabel endogennya akan mendekati variabel endogen itu sendiri. Jika $\mathrm{R}^{2}$ hasil regresi tahap pertama bernilai sangat kecil, hasil 2SLS dinilai tidak berarti karena hal ini prediktor variabel endogen yang dihasilkan tidak representatif (Gujarati \& Porter, 2008).

\section{Validasi dan Simulasi}

Validasi adalah tahap pengujian apakah suatu model dapat melakukan simulasi atau peramalan dengan mengikuti data yang sebenarnya. Validasi dilakukan untuk mengukur akurasi model (yang merupakan keterkaitan antar persamaan), jika digunakan untuk peramalan. Beberapa kriteria statistik (goodness of fit statistics) yang digunakan dalam penelitian ini adalah Root Mean Square Percent Error (RMSPE) dan koefisien U-Theil. RMSPE menggambarkan seberapa jauh nilai-nilai simulasi endogen menyimpang dari nilai aktualnya. Jika nilai ini semakin kecil, model disimpulkan semakin valid. Sementara itu, Root Mean Square Error (RMSE) adalah rata-rata kuadrat dari perbedaan nilai estimasi dan nilai pengamatan (aktual) (Pindyck dan Rubinfeld, 1991). Koefisien U-Theil (U) adalah perbandingan Root Mean Square Error dengan rata-rata kuadrat nilai pengamatan variabel endogen. Ukuran ini adalah salah satu statistik yang digunakan untuk mengevaluasi peramalan (Bliemel, 1973). Koefisien UTheil berkisar diantara $0-\infty$. Jika nilai $\mathrm{U}<1$, kemampuan model untuk melakukan peramalan dapat diterima. (Bliemel, 1973). Batasan yang jelas dalam kriteria ini mempermudah peneliti untuk menentukan suatu model valid atau tidak. 
Berikut rumus dari koefisien UTheil (Bliemel, 1973):

$U=\frac{\sqrt{\frac{1}{T} \sum_{t=1}^{n}\left(Y_{t}^{s}-Y_{t}^{a}\right)^{2}}}{\sqrt{\frac{1}{T} \sum_{t=1}^{n}\left(Y_{t}^{a}\right)^{2}}}$

Keterangan:

$U$ : koefisien U-Theil

$\mathrm{T}$ : jumlah pengamatan

$\mathrm{Y}_{\mathrm{t}}^{\mathrm{s}}$ : nilai dugaan model

$Y_{t}^{a}$ : nilai aktual

Sementara itu, RMSPE dapat diformulasikan sebagai berikut:

RMSPE $=\sqrt{\frac{1}{T} \sum_{t=1}^{n}\left(\frac{Y_{t}^{s}-Y_{t}^{a}}{Y_{t}^{a}}\right)^{2}}$

keterangan:

$\mathrm{T}$ : jumlah pengamatan

$Y_{t}^{s} \quad$ : nilai dugaan model

$Y_{t}^{a} \quad$ : nilai aktual

Dalam persamaan simultan, hubungan atau pengaruh tidak langsung suatu variabel dengan variabel yang tidak berada dalam satu persamaan tidak bisa dilihat dari signifikansi statistiknya. Secara teknis, hal tersebut tidak dapat dilihat meskipun keduanya saling berhubungan melalui variabel yang lain. Oleh karena itu, simulasi model penting dilakukan untuk melihat pengaruh variabel tersebut (Nasrudin, 2014). Simulasi bukan merupakan estimasi parameter, melainkan solusi matematis yang menghubungkan antar persamaan yang saling terkait dalam model. Maka, simulasi juga melibatkan persamaan identitas. Proses ini merupakan tahap akhir yang digunakan untuk menunjukkan pengaruh variabel eksogen terhadap variabel endogen di setiap persamaan struktural. Dalam penelitian ini dilakukan simulasi ex-post untuk mengevaluasi dampak dari guncangan mata uang RRT terhadap perekonomian Indonesia berdasarkan periode 2009-2014.

\section{HASIL DAN PEMBAHASAN}

Analisis Deskriptif Pergerakan Kurs Rupiah dan Yuan terhadap Dolar Amerika

Pola pergerakan kurs rupiah terhadap dolar dan yuan terhadap dolar dapat dilihat pada Gambar 1. Rupiah terdepresiasi secara signifikan saat periode krisis 1997-1998. Pada periode tersebut, Indonesia melepas kurs ke pasar karena pemerintah tidak sanggup lagi menahan tekanan pada stabilitas kurs. Sejak periode tersebut, rupiah cenderung terdepresiasi. Sejak tahun 2005, pergerakan kurs RRT bertolak belakang jika dibandingkan dengan pergerakan kurs Indonesia. Di saat kurs RRT mengalami revaluasi atau penguatan, kurs Indonesia cenderung terdepresiasi atau pelemahan. 
Keterkaitan antara kurs RRT dan Indonesia yang bertolak belakang ini menunjukkan indikasi bahwa produk Indonesia belum dapat bersaing dengan produk RRT meskipun harga RRT relatif lebih mahal dibandingkan Indonesia.

Sementara itu, pada tahun 2015, RRT melakukan devaluasi yuan sebesar 1,9\% untuk memulihkan perlambatan pertumbuhan ekonomi di RRT. Hal tersebut berakibat pada semakin terdepresiasinya nilai rupiah. Hal ini diindikasikan karena devaluasi yuan membuat harga RRT relatif lebih murah dibandingkan Indonesia sehingga Indonesia akan cenderung mengimpor produk-produk dari RRT. Selain itu, daya saing produk Indonesia di negara-negara lain juga diindikasikan menurun dibandingkan produk RRT akibat harga produk RRT relatif lebih murah sehingga ekspor Indonesia menurun. Penurunan ekspor Indonesia ini menyebabkan rupiah semakin terdepresiasi.

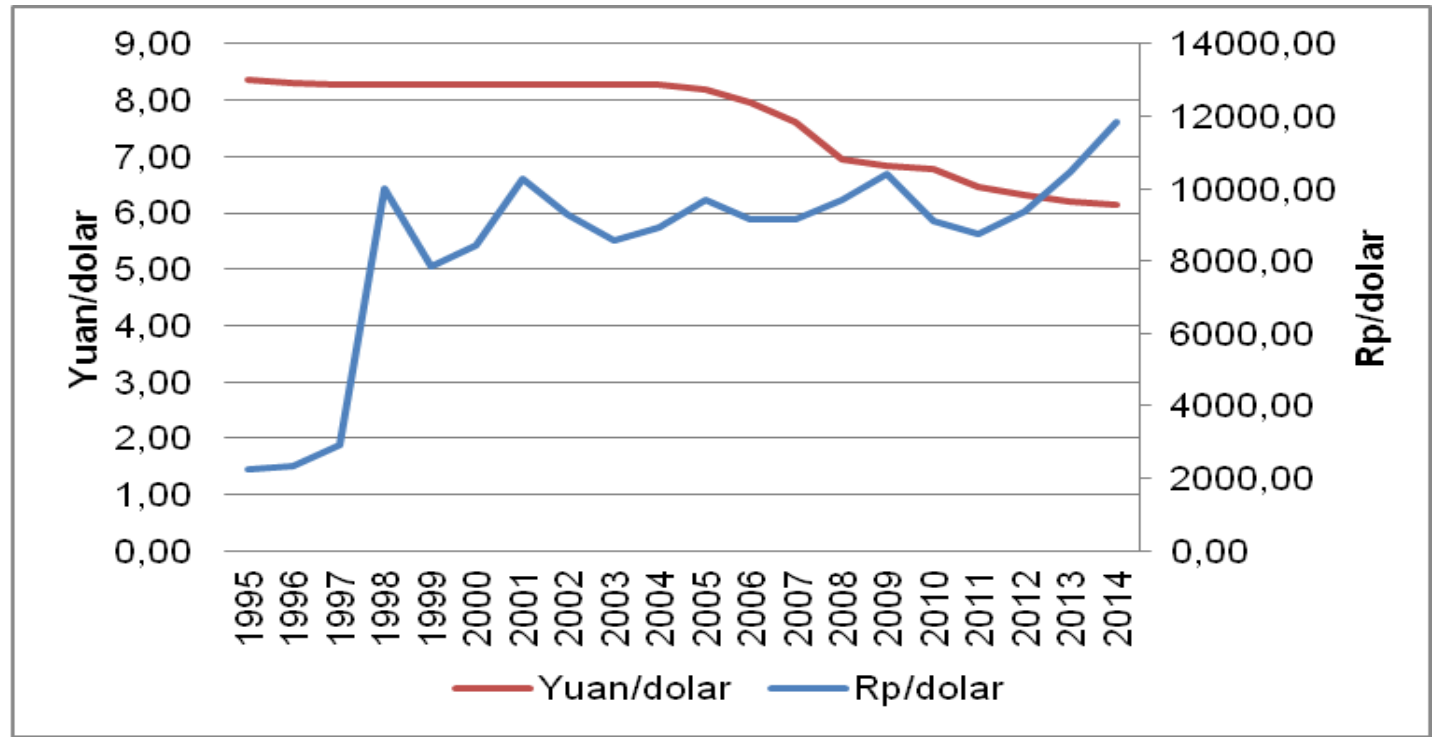

\section{Gambar 1. Pergerakan Kurs Rupiah dan Yuan terhadap Dolar Amerika}

Sumber: https://data.worldbank.org (2016), diolah

\section{Hasil Estimasi Secara Umum}

Hasil estimasi parameter 14 persamaan struktural pada penelitian ini secara umum telah memenuhi kriteria ekonomi, kriteria ekonometrik, serta kriteria statistik. Kriteria statistik tersebut ditunjukkan pada Tabel 1.
Pada tabel tersebut terlihat bahwa seluruh persamaan tersebut memenuhi kriteria overall- $F$ test dalam tingkat signifikansi $1 \%$, kecuali untuk variabel FDI US ke Indonesia (IA). Hal ini dapat dilihat dari $p$-value pada Tabel 1. Nilai ini berarti minimal terdapat satu 
variabel explanatory untuk semua persamaan memiliki pengaruh yang signifikan terhadap variabel endogennya dalam tingkat signifikansi $1 \%$, kecuali IA yang berada pada signifikansi $5 \%$.

Seluruh persamaan memiliki adj $R$-Sq yang kuat, kecuali untuk FDI US ke Indonesia hanya sebesar 0,33 . Hal ini menunjukkan bahwa seluruh variabel explanatory setiap persamaan dapat menjelaskan keragaman variabel endogen dengan baik. Seluruh persamaan juga telah memenuhi kriteria ekonometrik, yaitu terpenuhinya semua asumsi klasik.
Dapat disimpulkan bahwa model yang dibentuk dalam penelitian ini dapat digunakan menjelaskan keterkaitan perekonomian RRT terhadap perekonomian Indonesia. Kriteria statistik yang dijelaskan di atas menunjukkan model yang terbentuk sudah representatif. Persamaan-persamaan dibagi menjadi tiga blok, yakni blok perdagangan, blok investasi, dan blok moneter. Analisis hubungan antara variabel bebas dan tidak bebas di setiap persamaan pada penjelasan berikutnya menggunakan prinsip ceteris paribus, artinya pengaruh tersebut berlaku disaat variabel lainnya dianggap konstan atau tetap.

\section{Tabel 1. Hasil Kriteria-Kriteria Statistik Pada Setiap Persamaan}

\begin{tabular}{clclrlc}
\hline No & \multicolumn{1}{c}{ Persamaan } & Simbol & Adj $R$-Sq & \multicolumn{1}{c}{$\mathrm{F}$ stat } & P-value & Asumsi Klasik \\
\hline 1. & Impor Indonesia dari ROW & $\mathrm{MR}$ & 0,98 & 230,43 & 0,0001 & terpenuhi \\
2. & Impor Indonesia dari US & $\mathrm{MA}$ & 0,69 & 11,66 & 0,0002 & terpenuhi \\
3. & Impor Indonesia dari RRT & $\mathrm{MC}$ & 0,99 & 377,48 & 0,0001 & terpenuhi \\
4. & Ekspor Indonesia ke ROW & $\mathrm{XR}$ & 0,83 & 46,48 & 0,0001 & terpenuhi \\
5. & Ekspor Indonesia ke US & $\mathrm{XA}$ & 0,96 & 109,13 & 0,0001 & terpenuhi \\
6. & Ekspor Indonesia ke RRT & $\mathrm{XC}$ & 0,94 & 104,49 & 0,0001 & terpenuhi \\
7. & Inflasi & $\mathrm{Ti}$ & 0,84 & 33,45 & 0,0001 & terpenuhi \\
8. & Kurs & $\mathrm{EI}$ & 0,74 & 19,08 & 0,0001 & terpenuhi \\
9. & Deposit rate & $\mathrm{DRATE}$ & 0,98 & 360,80 & 0,0001 & terpenuhi \\
10. & Lending rate & $\mathrm{RI}$ & 0,75 & 20,17 & 0,0001 & terpenuhi \\
11. & PMDN & $\mathrm{DI}$ & 0,65 & 13,01 & 0,0001 & terpenuhi \\
12. & FDI dari RRT & $\mathrm{IC}$ & 0,69 & 9,47 & 0,0004 & terpenuhi \\
13. & FDI dari ROW & $\mathrm{IR}$ & 0,62 & 7,24 & 0,0015 & terpenuhi \\
14. & FDI dari US & $\mathrm{IA}$ & 0,33 & 4,10 & 0,0245 & terpenuhi \\
\hline Ken & & & & &
\end{tabular}

Keterangan:

US adalah United States/Amerika Serikat; ROW adalah Rest of the World

$P$-value merujuk pada $F$ stat 
Validasi

Validasi dan simulasi pada penelitian ini dilakukan pada rentang waktu 2009-2014. Periode tersebut dipilih untuk menghindari adanya periode krisis dan mewakili kondisi terbaru sehingga hasil simulasi dapat sesuai dengan keadaan sebenarnya. Berdasarkan hasil validasi menggunakan Root Mean Square Percent Error (RMPSE) dan koefisien UTheil, secara umum model disimpulkan valid untuk digunakan dalam peramalan. Hal tersebut ditunjukkan dengan nilai RMSPE dan koefisien U-Theil yang relatif rendah. Namun terdapat persamaan yang perlu berhati-hati untuk dianalisa karena memiliki RMSPE yang relatif besar, yakni persamaan investasi asing yang berasal dari Amerika Serikat (FDla). Nilai RMSPE yang relatif besar menunjukkan persamaan tersebut memiliki validitas yang rendah. FDla memiliki nilai tertinggi pada nilai RMSPE menunjukkan bahwa persamaan tersebut paling rendah validitasnya dalam melakukan peramalan dibanding persamaan lainnya. Tingginya RMSPE ini disebabkan nilai prediksi yang dihasilkan jauh dari nilai aktualnya. Hal tersebut juga ditunjukkan dengan nilai Adj $R$-Sq yang rendah pada persamaan tersebut.

Akan tetapi, jika kita melihat nilai U-Theil secara keseluruhan, nilai koefisien U-Theil untuk seluruh persamaan mendekati nol, dengan nilai tertinggi 0,29 (persamaan INFCI). Berdasarkan penelitian Bliemel (1973), hal ini menunjukkan model yang dibangun pada model ini masih dapat digunakan untuk peramalan meskipun terdapat beberapa persamaan yang memiliki nilai RMSPE yang relatif besar. Oleh karena itu, tahap simulasi pada penelitian ini dapat dilakukan. Hasil validasi secara menyeluruh dapat dilihat pada Tabel 2. 
Tabel 2. RMSPE dan Koefisien U-Theil setiap persamaan dalam model

\begin{tabular}{|c|c|c|c|c|c|c|}
\hline \multirow{2}{*}{ Variabel } & \multirow{2}{*}{$\mathrm{N}$} & \multirow{2}{*}{$\begin{array}{c}\text { RMSPE } \\
(\%)\end{array}$} & \multicolumn{3}{|c|}{ MSE Decomposision Propotion } & \multirow{2}{*}{$\begin{array}{c}\text { Koefisien } \\
\text { U-Theil }\end{array}$} \\
\hline & & & Bias (UM) & Var (US) & Covar (UC) & \\
\hline (1) & (2) & (3) & (4) & (5) & (6) & (7) \\
\hline NXC & 6 & 2,61 & 0,01 & 0,00 & 0,99 & 0,03 \\
\hline INFCl & 6 & 16,80 & 0,17 & 0,48 & 0,35 & 0,29 \\
\hline Y & 6 & 1,15 & 0,03 & 0,04 & 0,94 & 0,01 \\
\hline I & 6 & 12,73 & 0,00 & 0,10 & 0,90 & 0,09 \\
\hline DI & 6 & 21,03 & 0,32 & 0,10 & 0,58 & 0,14 \\
\hline FDI & 6 & 12,73 & 0,00 & 0,10 & 0,90 & 0,09 \\
\hline FDIC & 6 & 15,11 & 0,08 & 0,06 & 0,86 & 0,03 \\
\hline FDIA & 6 & 87,26 & 0,06 & 0,22 & 0,73 & 0,21 \\
\hline FDIR & 6 & 11,53 & 0,00 & 0,09 & 0,91 & 0,08 \\
\hline $\mathrm{X}$ & 6 & 4,46 & 0,00 & 0,33 & 0,67 & 0,04 \\
\hline $\mathrm{XIC}$ & 6 & 0,63 & 0,12 & 0,14 & 0,74 & 0,01 \\
\hline XIA & 6 & 0,72 & 0,11 & 0,00 & 0,89 & 0,01 \\
\hline XIR & 6 & 5,28 & 0,00 & 0,31 & 0,69 & 0,05 \\
\hline M & 6 & 1,46 & 0,33 & 0,28 & 0,38 & 0,01 \\
\hline MIA & 6 & 4,27 & 0,13 & 0,63 & 0,24 & 0,04 \\
\hline MIC & 6 & 3,11 & 0,01 & 0,04 & 0,95 & 0,02 \\
\hline MIR & 6 & 1,90 & 0,33 & 0,19 & 0,48 & 0,02 \\
\hline EI & 6 & 6,03 & 0,33 & 0,18 & 0,50 & 0,06 \\
\hline INFI & 6 & 16,80 & 0,16 & 0,16 & 0,68 & 0,17 \\
\hline RI & 6 & 5,62 & 0,28 & 0,20 & 0,52 & 0,06 \\
\hline RRI & 6 & 7,62 & 0,28 & 0,02 & 0,70 & 0,08 \\
\hline $\mathrm{RCl}$ & 6 & 13,58 & 0,33 & 0,00 & 0,67 & 0,10 \\
\hline DRATE & 6 & 13,58 & 0,28 & 0,04 & 0,68 & 0,16 \\
\hline EA & 6 & 6,03 & 0,33 & 0,06 & 0,61 & 0,06 \\
\hline $\mathrm{ECl}$ & 6 & 6,03 & 0,30 & 0,21 & 0,50 & 0,07 \\
\hline INFAI & 6 & 16,80 & 0,17 & 0,43 & 0,40 & 0,27 \\
\hline
\end{tabular}

\section{Hasil Simulasi}

Tabel 3 menunjukkan hasil simulasi dampak devaluasi yuan terhadap perekonomian Indonesia. Nilai dasar yang digunakan adalah kondisi sebelum yuan didevaluasi atau pada level 6,2 yuan/USD. Berdasarkan tabel di atas, devaluasi yuan menjadi 7 yuan/USD akan berdampak pada penurunan PDB riil Indonesia sebesar 0,1858\% jika dibandingkan dengan PDB saat tidak terjadi devaluasi. Penurunan ini terutama diakibatkan oleh penurunan total ekspor sebesar $0,4689 \%$.
Penurunan ekspor lebih besar dibandingkan penurunan PDB riil Indonesia disebabkan PDB Indonesia tidak hanya disusun oleh komponen ekspor.

Pada blok perdagangan, penurunan terbesar terjadi pada ekspor Indonesia ke RRT dan terjadinya peningkatan impor Indonesia terbesar dari RRT. Simulasi ini didukung oleh simulasi yang dilakukan oleh penelitian Jamilah et al (2016). Devaluasi Yuan menjadi 7 Yuan/USD memberikan dampak spillover terdepresiasinya 
rupiah sebesar $1,69 \%$. Lebih tingginya devaluasi Yuan relatif terhadap terjadinya depresiasi rupiah menyebabkan harga barang impor di RRT menjadi relatif lebih mahal dari sebelumnya, termasuk impor RRT dari Indonesia. Hal ini menyebabkan ekspor Indonesia ke RRT menurun sebesar $1,1441 \%$ dan permintaan impor dari RRT meningkat sebesar 0,1378\%. Selain itu, komoditi RRT yang lebih kompetitif membuat pangsa pasar Indonesia di dunia direbut oleh RRT. Hal ini ditunjukkan dengan penurunan ekspor Indonesia ke ROW sebesar $0,4837 \%$. Berdasarkan data rata-rata ekspor per komoditi dari unctad pada periode simulasi tersebut, 7 dari 10 komoditi ekspor terbesar Indonesia juga termasuk dalam 10 besar ekspor RRT terbesar ke dunia. Adanya indikasi negara-negara ROW lebih memilih komoditi tersebut dari RRT dibandingkan Indonesia menjadi fenomena dibalik penurunan ekspor Indonesia ke ROW. Fenomena ini seperti yang terjadi pada Ekonomi India yang dijelaskan oleh penelitian Chaitanya (2016) dan Rizwana (2015).

Terdepresiasinya nilai tukar rupiah akibat devaluasi yuan juga sesuai dengan salah satu penyebab contagion yang dijelaskan oleh Claessens dan Forbes (2004), yakni competitiveness devaluation melalui trade linkages. Teori ini menjelaskan bahwa depresiasi suatu mata uang akan membuat terdepresiasinya nilai mata uang negara lain karena takut kehilangan daya saingnya di pasar dunia.

Pada blok investasi, devaluasi RRT menyebabkan total investasi Indonesia meningkat sebesar 0,2497\%. Peningkatan ini disebabkan adanya aliran modal yang masuk, terutama dari RRT. Selain itu, terdapat pula peningkatan investasi dari ROW. Hal ini salah satu fenomena menarik yang diindikasikan terjadi karena tingkat pengembalian modal di RRT menjadi lebih rendah akibat devaluasi yuan. Oleh karena itu, para investor yang semula berinvestasi di RRT, investor RRT maupun ROW, lebih memilih beralih berinvestasi ke Indonesia. Fenomena ini didukung oleh penelitian Jin dan Zang (2013). Hal ini diperkuat dengan fenomena peningkatan FDI dari RRT pada tahun 2015 lalu. BKPM merilis realisasi investasi kumulatif Januari-September 2015 mencapai Rp 400 triliun, meningkat 16,7\% dibandingkan periode yang sama tahun 
sebelumnya, sebesar Rp 342 triliun. tahun 2014 sebesar

Selain itu, nilai pengajuan izin prinsip triliun.

RRT tahun 2015 naik $67 \%$ dibandingkan

Tabel 3. Dampak Devaluasi Yuan terhadap Perekonomian Indonesia

\begin{tabular}{lcrrr}
\hline \multicolumn{1}{c}{ Variabel } & Simbol & Nilai Dasar & Nilai Simulasi & Perubahan (\%) \\
\hline A. Moneter & & & & \\
PDB riil Indonesia & Y & 298767,0 & 298212,0 & $-0,1858$ \\
Kurs riil (Rp/\$) & EA & 7013,7 & 7131,6 & 1,6810 \\
Inflasi & Mi & 4,8 & 5,1 & ${ }^{*} 0,2720$ \\
Lending Rate & RI & 12,2 & 12,3 & ${ }^{*} 0,1097$ \\
Deposit Rate & DRATE & 6,6 & 6,8 & ${ }^{*} 0,1519$ \\
\hline B. Perdagangan & & & & \\
Total Ekspor & X & 106200,0 & 105702,0 & $-0,4689$ \\
Total Impor & M & 103912,0 & 103997,0 & 0,0818 \\
Ekspor Ind ke RRT & XC & 9841,8 & 9729,2 & $-1,1441$ \\
Ekspor Ind ke US & XA & 7854,8 & 7897,8 & 0,5474 \\
Ekspor Ind ke ROW & XR & 88503,5 & 88075,4 & $-0,4837$ \\
Impor Ind dari US & MR & 4317,5 & 4269,9 & $-1,1025$ \\
Impor Ind dari RRT & MC & 13928,8 & 13948,0 & 0,1378 \\
Impor Ind dari ROW & MR & 85665,8 & 85779,5 & 0,1327 \\
\hline C.Investasi & & & & \\
Total Investasi & I & 11414,8 & 11443,1 & 0,2497 \\
Investasi Domestik & DI & 5,2 & 5,2 & $-0,8136$ \\
Investasi Asing & FDI & 11409,6 & 11438,0 & 0,2489 \\
Investasi dari RRT & IC & 138,2 & 147,3 & 6,5847 \\
Investasi dari US & IA & 696,1 & 687,9 & $-1,1780$ \\
Investasi ROW & IR & 10575,3 & 10602,8 & 0,2600 \\
\hline
\end{tabular}

Keterangan: *Satuan dalam \% poin

Pada blok moneter, devaluasi Yuan berdampak pada penurunan ekspor neto Indonesia karena RRT merupakan mitra dagang utama selain US, Jepang, dan Singapura. Penurunan ekspor neto mendorong Rupiah terdepresiasi. Terdepresiasinya rupiah memicu kenaikan harga barang-barang impor (imported inflation), sehingga inflasi meningkat sebesar $0,2720 \%$ poin. Imported inflation tersebut terjadi karena ketergantungan Indonesia terhadap barang impor, baik barang modal, bahan baku maupun barang konsumsi. Saat rupiah terdepresiasi, harga impor menjadi relatif lebih mahal sehingga meningkatkan inflasi, sesuai dengan penelitian Imimole \& Enomo (2011). 
Kenaikan inflasi ini memicu lending rate meningkat sebesar $0,1097 \%$ poin, dan deposit rate meningkat sebesar $0,1519 \%$ poin. Sementara itu, tingkat suku bunga meningkat akibat respon untuk menekan kenaikan inflasi. Peningkatan tingkat suku bunga dimaksudkan untuk membuat masyarakat lebih memilih menabung dibanding konsumsi. Kenaikan tingkat suku bunga ini bertujuan untuk menurunkan permintaan barang dan jumlah uang beredar sehingga laju inflasi dapat ditekan. Menurut Wimanda et al (2014), suku bunga merupakan jalur transmisi paling utama dalam mengatasi masalah inflasi.

Dari dua jalur transmisi masuknya dampak gejolak devaluasi yuan ke perekonomian Indonesia, terlihat bahwa jalur perdagangan dapat menyalurkan dampak yang lebih besar dibandingkan jalur investasi. Hal ini dapat disimpulkan dari perubahan total ekspor impor yang lebih besar dibandingkan perubahan total investasi. Penurunan yang lebih besar pada total pendapatan perdagangan dibanding penambahan pendapatan dari total investasi inilah yang menyebabkan penurunan pendapatan Indonesia secara agregrat.
Hasil ini juga sekaligus membuktikan bahwa perekonomian Indonesia memiliki ketergantungan yang besar pada perekonomian RRT, terutama gejolak yang dapat memengaruhi Indonesia melalui jalur perdagangan.

\section{KESIMPULAN DAN REKOMENDASI KEBIJAKAN}

Pada akhir 2015, perlambatan pertumbuhan ekonomi RRT memaksa pemerintah RRT untuk mendevaluasi yuan terhadap dolar Amerika hampir $2 \%$. Devaluasi ini bertujuan untuk mendorong kinerja ekspor maupun menarik FDI ke RRT akibat biaya produksi menjadi lebih murah sehingga diharapkan dapat meningkatkan kembali ekonomi mereka.

Devaluasi yuan tersebut secara umum berdampak negatif terhadap perekonomian Indonesia. Hal ini dapat disimpulkan dari adanya kenaikan inflasi, depresiasi nilai tukar yang disertai penurunan pendapatan nasional Indonesia. Gejolak ini ditransmisi secara signifikan melalui dua jalur, yakni jalur perdagangan dan jalur investasi.

Pada jalur perdagangan, Indonesia mengalami penurunan ekspor dan peningkatan impor. Penurunan terbesar terdapat pada ekspor 
Indonesia ke RRT. Hal ini disebabkan harga produk Indonesia menjadi relatif lebih mahal dibandingkan RRT karena rupiah terdepresiasi lebih rendah dibandingkan devaluasi yuan.

Sementara itu, pada jalur investasi terjadi hal yang menarik. Dengan didevaluasinya Yuan, RRT malah lebih meningkatkan FDI RRT ke Indonesia dibandingkan memberikan prioritas kepada peningkatan investasi dalam negeri RRT. Hal ini disebabkan karena adanya penurunan kekayaan investor di RRT saat terjadi devaluasi yuan.

Penurunan pendapatan dari blok perdagangan yang lebih besar dibandingkan penambahan pendapatan pada blok investasi menyebabkan secara agregrat pendapatan menjadi menurun. Simulasi ini menunjukkan bahwa dampak devaluasi yuan lebih dominan melalui jalur perdagangan dibandingkan jalur investasi. Hal ini mengindikasikan besarnya ketergantungan Indonesia terhadap gejolak ekonomi yang terjadi di RRT terutama pada blok perdagangan.

Dari kesimpulan di atas, agar dampak negatif dari devaluasi yuan dapat diminimalisasi, pemerintah harus lebih mengurangi ketergantungan terhadap RRT, terutama dari sisi perdagangan. Hal ini dapat dilakukan salah satunya dengan melakukan diversifikasi pasar dan produk ekspor. Selain itu peningkatan kualitas produk harus diperhatikan agar saat terjadi penurunan harga relatif dari negara lain, terutama RRT, produk Indonesia masih tetap dapat bersaing dengan produk tersebut. Hal ini bertujuan untuk meminimalisasi permintaan produk ekspor menurun secara signifikan. Sementara itu, dari sisi investasi, Indonesia juga harus menyiapkan infrastruktur, stabilitas perekonomian, dan regulasi yang baik dalam menyambut investor RRT yang diindikasikan akan meningkat saat adanya devaluasi yuan. Kemudahan dalam investasi di Indonesia diharapkan dapat mendorong investasi yang lebih besar sehingga dapat menutupi penurunan pendapatan dari sumber perdagangan.

Untuk penelitian selanjutnya, diharapkan dapat meneruskan penelitian mengenai alternatif kebijakan yang dapat diambil pemerintah untuk mengurangi ketergantungan Indonesia terhadap RRT dan penguatan fundamental ekonomi dalam negeri terhadap ketidakstabilan gejolak eksternal. 
UCAPAN TERIMA KASIH

Penulis mengucapkan terima kasih kepada pihak yang telah mendukung penyusunan naskah ilmiah ini, terutama kepada Novia Budi Parwanto, M.S.E., M.P.P, Ph.D., Ribut Nurul Tri Wahyuni, SST., M.S.E, dan R. Dwi Harwin Kusmaryo, SE, MA atas masukan dan beberapa pertanyaan yang membangun dalam penelitian ini.

\section{DAFTAR PUSTAKA}

BPS. (2016). Produk Domestik Bruto Indonesia Menurut pengeluaran Tahun 2011- 2015. Jakarta: BPS.

Bliemel, F. (1973). Theil's Forecast Accuracy Coefficient: A Clarification. Journal of Marketing Research, Vol. 10(4), pp.444-446.

Bloomberg. (2016, Juni 29). China Said to Intervene in Offshore Yuan Market to Curb Declines. Bloomberg News. Diakses pada tanggal 8 Juli 2016 dari

http://www.bloomberg.com/news/arti cles/2016-06-29/china-s-yuanstrengthens-for-second-day-asbrexit-turmoil-abates.

Chaitanya. (2016). Impact of Devaluation of Yuan on Indian Economy and Select Global Stock Indices. International Journal of Management and Business Studies. Vol. 6(1). pp.14-16

Claessens dan Forbes. (2004). International Financial Contagion: The Theory, Evidence and Policy Implications. IMF's conference.

CNBC Staf. (2016, Maret 14). Chinese Yuan May Weaken to 7 Against Dollar By Year End Goldman Sachs Says. CNBC. Diakses pada tanggal 8 Juli 2016 dari http://www.cnbc.com/2016/03/14/chi nese-yuan-may-weaken-to-7against-dollar-by-year-end-goldmansachs-says.html.

DBS Group Research (2015). Economic Singapore when China Devalues. DBS Bank Ltd.

Forbes, Kristin. (2012). THE "BIG C": IDENTIFYING CONTAGION. Working Paper, NBER, 18465.

Gujarati, D. dan Porter. (2008). Basic Econometrics $5^{\text {th }}$ edition. New York: McGraw-Hill.

Harahap, A.B., Bary, P., Nurliana, L., Satyanugroho, R. (2015). Dampak Spillover Shock Eksternal Pada Perekonomian Indonesia: Pendekatan Global VAR. Working Paper Bank Indonesia WP/2/2015.

Hooy, Law, dan Chan. (2015). The Impact of Renminbi Real Exchange Rate on ASEAN Disaggregated Export to China. Economic Modelling. Vol 4. pp.253-259.

IMF. (2016). Subdued Demand, Diminished Prospects. World Economy Outlook Update.

Imimole \& Enomo. (2011). Exchange Rate Depreciation and Inflation in Nigeria (1986-2008). Business and Economics Journal.

Jamilah, Sinaga, Tambunan dan Hakim. (2016). Dampak Perlambatan Ekonomi China dan Devaluasi Yuan Terhadap Kinerja Perdagangan Pertanian Indonesia. Ekuitas: Jurnal Ekonomi dan Keuangan. Vol. 20 No.3 pp. 325-245.

Jin, W., dan Zang Q. (2013). Impact of Change in Exchange Rate on Foreign Direct Investment: Evidence from China. Lingnan Journal of Banking, Finance, and Economics. Vol 4. pp.1-17.

Mar'ah, Suhadak dan Hidayat. (2016). Pengaruh Perubahan Nilai Tukar Tiongkok Terhadap US Dollar Amerika Serikat dan Dampaknya Terhadap Rupiah Indonesia (Studi 
pada Bloomberg dan Bank Indonesia 2012-2015). Jurnal Administrasi Bisnis. Vol.35 No.2 pp.46-52

Nasrudin. (2014). Dampak Kebijakan Fiskal Terhadap Kinerja Perekonomian \& Sektor Pertanian Indonesia Pada Integrasi Ekonomi Regional ChinaAsean [Disertasi]. Bogor: Institut Pertanian Bogor.

Pindyck \& Rubinfeld. (1991). Econometric Models and Ecconomic Forecast. New York: McGraw-Hill.

Rizwana, H. (2015). Yuan Depreciation and Its Impact. Asian Journal of Research in Business Economics and Management. Vol. 5 No.12. pp.61-66.

Sari, Elisa V. (2015). Gubernur Bl: Ekonomi RI 2016 Dihantui Tiga Risiko Eksternal." CNN Indonesia. Diakses pada tanggal 28 Juni 2016 dari http://www.cnnindonesia.com/ekono $\mathrm{mi} / 20151124194705-78-$

3796/gubernur-bi-ekonomi-ri-2016dihantui-tiga-risiko-eksternal.
Shik. (2016). Renminbi Depreciation and the Hong Kong Economy. Hong Kong Economic Montly, Hang Seng Bank.

Soleymani, Chua, dan Fattah. (2016). The Effect of Currency Depreciation on Industry Trade Flow Between Malaysia and China. The International Trade Journal. DOI:10.1080/08853908.2016.11389 08.

Winanda, Maryaningsih, Nurliana, dan Satyanugroho. (2014). Evaluasi Transmisi Bauran Kebijakan Bank Indonesia. Working Paper Bank Indonesia WP/3/2014.

Wooldridge, Jeffrey M. (2012). Introductory Econometrics: A Modern Approach, $5^{\text {th }}$ Edition.United States: Cengage Learning.

Worldbank. (2016). Data dari Internet Tentang Kurs. Diunduh tanggal 25 Februari 2016 https://data.worldbank.org. 
